\title{
Correction to: HIV Infection and Neurocognitive Disorders in the Context of Chronic Drug Abuse: Evidence for Divergent Findings Dependent upon Prior Drug History
}

\author{
Jessica M. Illenberger ${ }^{1}$ (D) $\cdot$ Steven B. Harrod $^{1}$ (D) $\cdot$ Charles F. Mactutus $^{1}$ (D) $\cdot$ Kristen A. McLaurin $^{1}$ (D) $\cdot$ Asha Kallianpur $^{2}$ (D) \\ Rosemarie M. Booze ${ }^{1}$ (B)
}

Published online: 28 July 2020

(C) Springer Science+Business Media, LLC, part of Springer Nature 2020

\section{Correction to: Journal of Neuroimmune Pharmacology. https://doi.org/10.1007/s11481-020-09928-5}

Corrected references:

Kumar AM, Fernandez JB, Singer EJ, Commins D, WaldropValverde D, Ownby RL, Kumar M (2009) Human immunodeficiency virus type 1 in the central nervous system leads to decreased dopamine in different regions of postmortem human brains. J Neurovirol 15(3): 257-274

Kumar AM, Ownby RL, Waldrop-Valverde D, Fernandez B, Kumar M (2011) Human immunodeficiency virus infection in the CNS and decreased dopamine availability: relationship with neuropsychologal performance. J Neurovirol 17(1):26-40

Corrected sentence in Interactions between the Effects of Drug Use and HIV-1 Infection Leads to Accelerated Disease Progression: "White matter damage (Tang et al. 2015; Alakkas et al. 2019), mitochondrial dysfunction (Buch et al. 2011), and iron dysregulation (Drakesmith et al. 2005; Ersche et al. 2017) occur with cocaine use and have also been associated with HIV infection and HAND; these processes may therefore be promising targets for treatment development."

The online version of the original article can be found at https://doi.org/ 10.1007/s11481-020-09928-5

Rosemarie M. Booze

booze@mailbox.sc.edu

1 Department of Psychology, University of South Carolina, Columbia, SC, USA

2 Lerner Research Institute, Genomic Medicine Institute, Cleveland Clinic, Cleveland, OH, USA

Publisher's Note Springer Nature remains neutral with regard to jurisdictional claims in published maps and institutional affiliations. 